\title{
Increasing Knowledge and Promoting Better Attitude towards Appropriate Self-Medication in Sungai Ambawang Community through CBIA
}

\author{
Eka Kartika Untari*, Robiyanto, Pratiwi Apridamayanti, Muhammad Akib Yuswar, Rafika Sari, \\ Nera Umilia Purwanti, Ressi Susanti
}

Pharmacy Study Program, Faculty of Medicine, Tanjungpura University, Indonesia

Submitted: December 20 2019 ; Revised: March 10 ${ }^{\text {th }} 2021$; Accepted: June $13^{\text {th }} 2021$

$\begin{array}{ll}\text { Keywords: } & \text { Abstract Self-medication practice in the community tends to increase. One of } \\ \text { Attitude } & \text { the factors that influence this trend is the variation of non-prescription drugs } \\ \text { Behavior } & \text { and advertisements. Although in self-medication people are allowed to } \\ \text { CBIA } & \text { determine their own medication, but it has the potential to create problems. } \\ \text { Knowledge } & \text { Sungai Ambawang Sub-district is one of the trans Kalimantan; accordingly the } \\ \text { Self medication } & \text { medicine products from outside West Kalimantan can be transported through } \\ & \text { this area. This community service activity (PKM) aimed to increase knowledge } \\ & \text { and encourage positive attitudes, so that their behavior of self-medication } \\ & \text { becomes appropriate. This PKM was carried out by the method of community- } \\ & \text { based interactive approach (CBIA) in } 2 \text { steps. This activity involved } 66 \\ \text { community health center cadres. The participants knowledge and attitude } & \text { were measured twice (pretest and posttest) through questionnaires, then } \\ & \text { analyzed descriptively and statistically using the Wilcoxon test. The } \\ \text { observations showed that most of the participants had bought medicines } \\ \text { without a prescription for self-medication (78.7\%), obtained the medicine from } \\ \text { pharmacies (65.2\%), purchased medicines over the counter (45.4\%), and } \\ \text { frequently used analgesic-antipyretics (77\%). The results of the Wilcoxon test } \\ \text { showed that there were significant differences between knowledge and } \\ \text { attitudes before and after CBIA intervention. Based on the results of this } \\ \text { intervention, it was concluded that the CBIA intervention done as the PKM } \\ \text { activity could increase knowledge and encourage positive attitudes regarding } \\ \text { appropriate self-medication practices. }\end{array}$

\section{INTRODUCTION}

On average, $30.9 \%$ of Indonesian people experience illnesses in a month (BPS, 2007). The prevalence of non-prescription drug utilization is up to $68 \%$ in European countries. This figure is significantly increasing in developing countries (Bennadi, 2014). The practice of self-medication is influenced by many factors such as education, family, environment, policies, media exposure, and advertising. The public obtains information about self-medication from electronic media as well as drugs' packaging. Most of the information from electronic media contains descriptions that are difficult to understand, which can mislead their readers. One of the reasons for the practice of self-medication is the distance of health care facilities from people's home (Khairiyati, 2013).

One of the sub-districts that is directly adjacent to Pontianak City is Sungai Ambawang Sub-district. This

ISSN 2460-9447 (print), ISSN 2541-5883 (online)

*Corresponding author: Eka Kartika Untari

Pharmacy Study Program, Faculty of Medicine, Tanjungpura University, Jl. Profesor Dokter Haji Hadari Nawawi, Bansir Laut, Pontianak Tenggara, Kota Pontianak, Kalimantan Barat 78115, Indonesia

Email: ekakartika@pharm.untan.ac.id 
sub-district is also a crossing route between regencies in Borneo Island and has a route for goods and people who wish to go to Malaysia. This fact can encourage the distribution of illegal goods including medicinal products, supplements, and medical devices. Therefore, carrying out self-medication practices can be inappropriately carried out. Some of the reasons for people in doing self-medication include having homes far away from of health facilities, time constraints, and lower costs (Supardi \& Susyanty, 2010).

The most fully equipped of government health facility in Sungai Ambawang Sub-district is the Sungai Ambawang Community Health Center. This health center serves inpatient patients for 24 hours which include a general polyclinic, dental polyclinic, nutrition polyclinic, KIA (mother and child) polyclinic, laboratory, and pharmacy. In fact, it is the only community health center in Sungai Ambawang Subdistrict that is located on the Trans Kalimantan Road (Kubu Raya Regency Government, 2018). Communities in Sungai Ambawang Sub-district have the potential to practice self-medication because their residence is located far from any health facility. People there are highly likely to use or take drugs that are already at home, traditional medicines, or herbs rather than buying medicines in pharmacies that are far from their homes (sub-district).

The practice of self-medication must be carried out rationally by fulfilling indicators of rational use of drugs, namely: it is in accordance with the suffered disease, there is no contraindication, the disease is a minor disorder, and it is appropriate in terms of duration of treatment, and the types of drugs used are limited (Bennadi, 2014). The practice of self-medication might be prone to errors. The errors occurred in selfmedication will have negative impacts that these worsen the existing disease, increase the drugs' side effects, and increase their toxicity (BinFar Directorate, 2006). The limitation of public knowledge about medicine can be a source of medication errors in the implementation of self-medication. Almost $50 \%$ people practice self-medication that is not according to the rules. As a result, there is a tendency for self-medication practice to increase that leads to the possibility of an increase in errors in self-medication (Supardi et al., 2002).

In the past, the Indonesian government provided a program, Active Learning Methods for Mothers, to empower communities throughout the country in the field of health education. Media leaflets, lectures, and the Active Learning Methods for Mothers had succeeded in increasing the knowledge as well as encouraging positive attitudes and actions of female respondents. The Active Learning Methods for Mothers program has now changed into the Cara Belajar Insan Aktif (CBIA), loosely translated into people's active learning methods, which does not only involve housewives but also men of any positions and groups. Groups that are considered influential such as community leaders, religious leaders, students, youth groups, and other groups are also involved in this health-related effort as they are expected to become agents of change (Suryawati, 2003; Directorate General of BinFar, 2008).

The CBIA method has been one of the ways to increase people's knowledge and encourage both their positive attitudes and behavior, so that they can practice appropriate self-medication when necessary. Through this learning method, people not only can gain knowledge about the classes or types of medicines that may be used for their self-medication and how to use these medicines, but they also can determine the duration of their self-medication and the types of minor diseases that can be treated by self-medication practices (Dirjen BinFar, 2008). As a result, people will have knowledge in carrying out appropriate and safe selfmedication practices.

The purposes of this PKM activity were to increase the knowledge and encourage positive attitudes of Sungai Ambawang Sub-district's community in relationship to the appropriate and safe self-medication practice, provide education to this community regarding the classes and types of medicines that are allowed in the practice of selfmedication, and prevent the negative impacts of irrational self-medication practices.

\section{METHODS}

The PKM was carried out using the CBIA method which included two stages or meeting sessions. Each session lasted for two hours. The process of delivering the information or materials at each stage was conducted by the PKM team who were directly involved as resource persons. The PKM team members had educational backgrounds in pharmaceutical sciences, and they prepared these materials for the participants. In the first stage of the CBIA, participants learned how to recognize the minor illnesses that are allowed to be self-medicated. A minor illness is a disease that often occurs with a duration of no more than three days. It can be handled properly, does not cause symptoms of a chronic disease, and does not cause any emergency such as fever, cough, runny nose, acute diarrhea, and itching. The second stage involved how to understand the information on the medicine packaging. The packaging is the outermost package of the medicine product, for example the packaging box, the brochure inside the package, and the label attached to the product. 
The details of the CBIA stages were as follow.

1. CBIA stage I: recognizing minor diseases

a. The participants recalled and recorded minor illnesses that they had self-medicated, namely: fever, headache, cough, runny nose, diarrhea, toothache, and constipation.

b. The participants recalled and recorded selfmedication that they had practiced to overcome their complaints in relationship to the minor diseases on their record sheet.

c. The participants and the PKM team discussed the complaints or symptoms that were allowed to be self-medicated.

2. CBIA phase II: understanding information on drugs' packaging

a. PKM team distributed one package of over the counter (OTC) drugs which consisted of Bodrex: Bodrex Flu and Cough, Bodrex Migra tablets, Bodrexin, Panadol (Red, Blue, and Green), Mixagrip, Generic Paracetamol, Paracetamol syrup, Promag and Mylanta tablets, Oralit sachets, New Diatab, Neo Enterostop tablets, Vicks Formula 44 syrup, Hufagrip syrup, Daktarin ointment, Erlamicetin eye ointment, and Insto eye drops. Amoxicillin $500 \mathrm{mg}$ caplets were also included to check whether participants would know that it was not allowed for self-medication.

b. The participants observed the drugs' packaging and the types of available information.

c. The participants were asked to group the medicines based on the same active substance and record their observations and classifications.

d. The participants and the PKM team discussed the results of participants' observations and classification.

The PKM activity was undertaken in May 2018, in collaboration with cadres from Sungai Ambawang Community Health Center. The people of Sungai Ambawang who could take part in the CBIA were Ambawang Health Center cadres who could read and write. Those who did not completely fill out the questionnaire given were not allowed to participate in this program. The tools and equipment that were used during the PKM were medicine packages, loudspeakers, projectors, and white screens. A questionnaire was also used as a measurement tool. This questionnaire was valid and reliable based on a research conducted by Untari et al. (2017). The questionnaire measured the participants' knowledge of drugs and self-medication. It consisted of 14 questions with a dichotomous scale, which was true and false choices. The score of 1 was given for a correct answer, and the score of 0 for an incorrect answer. The scope of the questions serving to assess the participants' knowledge comprised the definition of self-medication, information on medicines' packaging, medicine class markers, examples of medicines, complaints that can be self-medicated, and how to use drugs. The questions that measured the participants' attitudes consisted of eight questions with a Likert scale (agree, undecided, and disagree). The explanation about the contents and purpose of this measurement was explained in advance to the participants before the filling process. After this, every participant was asked to sign an informed consent. The participants were asked to fill in the questionnaire (with the same questions) two times, which were shortly before stage 1 and after stage 2 was completed.

The data were presented descriptively in percentages. The results of knowledge and attitude measurement were presented as scores, and they were not homogeneously distributed. Therefore, a statistical analysis was continued using the Wilcoxon test with a 95\% significant level to determine whether there was a significant difference between before and after the CBIA.

\section{RESULT AND DISCUSSION}

Sungai Ambawang Sub-district is located in Kubu Raya Regency, which is a regency that borders Pontianak City. The number of Community Health Centers (Puskesmas) in Kubu Raya Regency is 20, 10 of which are equipped with beds, and the other 10 health centers are not equipped with beds. The 20 Puskesmas in Kubu Raya Regency have served the largest population residing in West Kalimantan, one of which has served around 27,270 residents (West Kalimantan Health Office, 2016). The cadres who were involved in this community service activity came from the Ambawang Community Health Center, one of the community health centers in Kubu Raya Regency. These cadres were recruited to participate in the CBIA program by giving them invitations and information about the PKM program that was similar to a community empowerment activity. The community health centers function to overcome or deal with public health problems and to pass on any information about health programs carried out or facilitated by the government. The cadres are the "spearheads" who play a role in the implementation of any health program launched by the government. They are an important component in ensuring the success of these programs. Initially, as many as 73 cadres were involved in the PKM activity, but only 66 cadres managed to complete the assessment questionnaire.

The CBIA learning program was carried out in two stages. Stage I of the CBIA aimed to make the participants understand the scope of self-medication practice, including the types of minor illnesses that may 
be self-medicated, and teach them to recognize the characteristics and symptoms of these minor illnesses. Minor ailments that were discussed during this learning activity comprised of fever, headache, cough, runny nose, diarrhea, toothache, and constipation. In this stage, the team leader presented the materials, and all of the participants were put in one "classroom" (Figure 1). In the first two hours, the participants listened to a lecture given by the team leader. Subsequently, for two hours the participants made some notes of the minor illnesses they had had in the past and self-medication they had taken for these minor illnesses. In this session, participants also had discussions with the resource people to evaluate the self-medication actions that they had done, so that the participants could understand whether their actions were medically correct or not. The rules or guidelines for correct self-medication state that this can only be done to treat minor ailments; one is only allowed to use non-prescription drugs according to the indications and instructions for their use; selfmedication should only last no more than three days. and if the disease persists, one should see a doctor.

Stage II of the CBIA aimed to train the participants to recognize the drug classes allowed for self-medication practice and help them understand the information written on drug packages. In this stage, drug packages were used as one of the learning media, which were given in addition to the materials delivered through a projector. These drug packages consisted of drugs with generic names and trade names. They were also used as the representatives of various drug classes except for psychotropics and narcotics, free drugs, limited-free drugs, drugs that can only be purchased at a pharmacy but do not require prescriptions (OWA), and prescription drugs. In addition, the variety of preparations in the drug packages consisted of tablets, caplets, powders, syrups, and ointments. The seven drug packages consisted of Bodrex (Bodrex Flu and Cough, Bodrex Migra tablets, Bodrexin), Panadol (Red, Blue, and Green), Mixagrip, Generic Paracetamol, Paracetamol syrup, Promag and Mylanta tablets, Oralit sachets, New Diatab, Neo Enterostop tablets, Vicks Formula 44 syrup, Hufagrip syrup, Daktarin ointment, Erlamicetin eye ointment, and Insto eye drops, each of which was one package or bottle. Amoxicillin $500 \mathrm{mg}$ caplets were added as a distractor. One package of drugs was given to each group during the FGD. These drugs were a sample used by the participants to learn to distinguish the classes of drugs allowed in selfmedication practice. This activity was also aimed to train the participants to read and understand the information written on drug packages. The information on drug packages comprised drug class logos, indications, contraindications, dosage, how to use, warnings when using, and information about their side effects.
The CBIA stage II was carried out through a Focus Group Discussion (FGD) format to make it easier for participants to understand the materials (Lathifah, Susanti, Ilham, \& Wibowo, 2017). The participants were divided into 6 small groups, each of which was coordinated by one team member and led by a team leader. The participants discussed and tried to classify the drugs while observing the drug samples in turn; each group was given one drug package (Figure 2).

Each stage of the CBIA learning program lasted for approximately four hours, during which the participants had discussions and were involved in question-and-answer sessions. The general purpose of the CBIA program was to facilitate the participants to practice self-medication appropriately or correctly. This means that they were expected to be able to practice self-medication only for mild symptoms or illness, use non-prescription drugs, self-medicate with a duration of not more than three days, and consult a doctor if the symptoms worsen. The documentation of the PKM activities is shown in Figures 1 and 2.

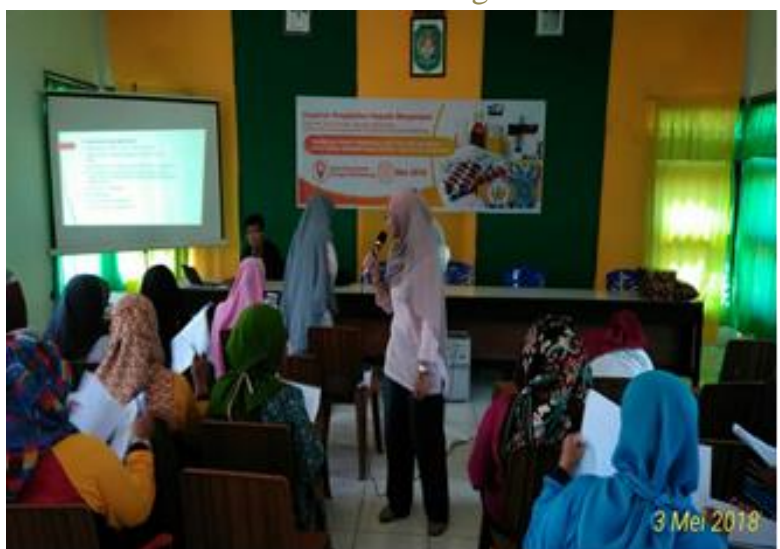

Figure 1. CBIA Stage I Source : Primary data (2018)

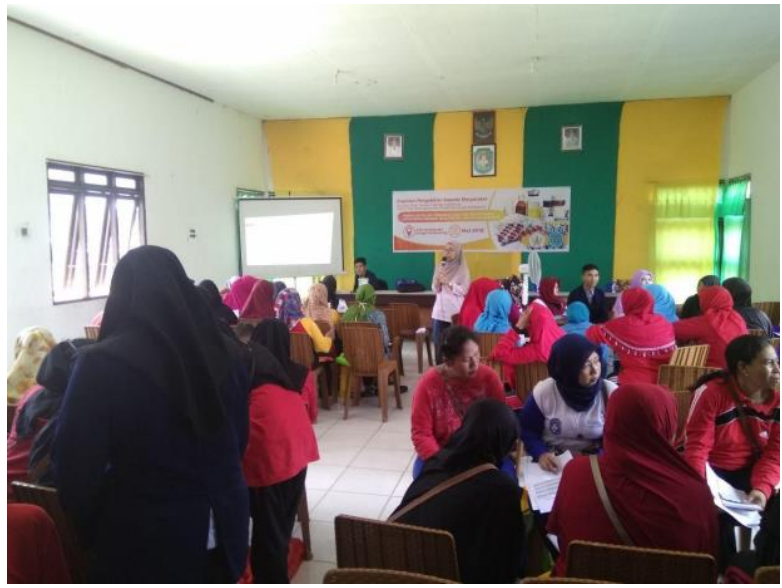

Figure 2. FGD in CBIA Stage 2

In order to evaluate the CBIA program, the participant were asked to fill in two questionnaires, one before the CBIA begins (pre-test) or before stage 1 and the other after the CBIA was carried out (post-test) or after stage 2 was completed. The participants who filled out the first questionnaire completely and could be processed were 66 out of 73 cadres. This questionnaire 
consists of questions regarding self-medication knowledge and both attitudes towards and behavior regarding self-medication. The outcomes of the CBIA program, measured using the questionnaires, showed increasing knowledge and the desirable behavior.

These listed in Table 1-4.

Table 1. Behavior of the PKM (CBIA) participants regarding self-medication practice $(n=66)$

\begin{tabular}{|c|c|c|c|}
\hline Self-medication behavior & & $\mathbf{n}$ & $\%$ \\
\hline \multirow[t]{4}{*}{ Where medications were bought } & Pharmacy & 43 & 65.2 \\
\hline & Drug Store & 8 & 12.2 \\
\hline & Mini market & 10 & 15.1 \\
\hline & Others & 5 & 7.5 \\
\hline \multirow[t]{2}{*}{ Kind of packages } & One Package & 45 & 68.2 \\
\hline & Part of package & 21 & 31.8 \\
\hline \multirow[t]{2}{*}{ Reading the instructions } & Yes & 65 & 98.5 \\
\hline & No & 1 & 1.5 \\
\hline \multirow[t]{2}{*}{ Noticing the warning sign } & Yes & 57 & 86.3 \\
\hline & No & 9 & 13.7 \\
\hline \multirow[t]{2}{*}{ Experience in using herbal } & Yes & 36 & 54.5 \\
\hline & Never & 30 & 45.5 \\
\hline \multirow{2}{*}{$\begin{array}{l}\text { Experience in buying medicines without prescription for } \\
\text { self-medication }\end{array}$} & Yes & 52 & 78.7 \\
\hline & No & 14 & 21.3 \\
\hline \multirow[t]{2}{*}{ Self-medication duration } & Not more than 3 days & 63 & 95.5 \\
\hline & More than 3 days & 3 & 4.5 \\
\hline
\end{tabular}

Table 2. The behavior of PKM (CBIA) participants in buying over-the-counter medicines (OTC) for self-medication practices $(n=52)$ 
History of medicine use

Over the counter (OTC)

20

45.4

Limited OTC

5

11.4

Pharmacy mandatory (OWA)

12

Cannot recall

7

16

Frequency of medicine use

1 time

2 times

10

19.2

3 times

25

48.2

Drug class therapy
Analgesic-antipyretic

Decongestant combinations

Antihistamine

Antacids

Others

(Traditional/Herbal Medicine)

Cannot recall
40

77

2

3

5

1

1.9

3.8

Table 3. Participants' improved knowledge and better attitude after the CBIA program $(n=66)$

\begin{tabular}{ccccc}
\hline & Not increase & & Increase \\
& $\mathbf{n}$ & $\boldsymbol{n}$ & $\mathbf{n}$ & $\%$ \\
\hline Knowledge & 15 & 22.73 & 51 & 87.27 \\
Attitude & 12 & 18.18 & 54 & 81.82 \\
\hline
\end{tabular}

Table 4. Differences in knowledge and attitude scores of the PKM participants before and after the CBIA program according to the Wilcoxon test $(n=66)$

\begin{tabular}{lcccccc}
\hline & & Min. & Max. & Average & SD & $p$ \\
\hline Knowledge & Pretest & 12 & 28 & 20.52 & 3.880 & 0.000 \\
& & & & & & \\
& Posttest & 18 & 28 & 24.61 & 1.888
\end{tabular}


Attitude

Pretest

3

16

11.53

3.672

0.000

In Table 1, we can see that most of the participants $(65.2 \%)$ bought medicines for their self-medication at pharmacies. This is in line with the location of the Sungai Ambawang Sub-district which has now developed into an urban area since it became a route for vehicles going from Pontianak to Malaysia. There were still participants who purchased drugs in retail packaging (31.8\%). The participants' behavior of buying drugs in retail or incomplete packaging resulted in incomplete information regarding the use of drugs listed in the packaging. Therefore, the possibility of undesirable events due to the use of wrong drugs was fairly high. However, the participants' behavior also showed a positive direction, one of which was that almost all participants had read how to use drugs (instructions) and pay attention to warning signs when they were going to use the drugs (Bennadi, 2014). The warning signs written on the packaging of limited overthe-counter drugs are needed to prevent excessive drug use. The allowed duration for the practice of selfmedication that is not more than three days. If the pain continues or becomes more severe or worsen, the practice of self-medication must be stopped. People should then consult a doctor. Most of the participants also understood that the duration of self-medication practice should not exceed three days.

Fifty-two people $(78.7 \%)$ of the total PKM participants (66 cadres) had purchased drugs without prescriptions (obat tanpa resep, OTR) for their selfmedication practices. The allowed OTR groups are over-the-counter drugs, limited over-the-counter drugs, and mandatory pharmacy (OWA) drugs. Table 2 shows the distribution of self-medication behavior or practices among 52 participants who had obtained drugs without their doctors' prescriptions. As shown in Table 2, most of the participants used over-the-counter drugs for their self-medication practices and used these drugs three times a day. Over-the-counter drugs are a class of drugs that have minimal side effects unless they are used in long periods and meet the criteria for drugs that may be used without doctors' prescriptions according to the Regulation of the Minister of Health Number 919/MenKes/PER/X/1993.

The frequency of drug use actually depends on the pharmacokinetic profile of the drug. However, the general understanding or perception of the general population is that the drugs are usually used three times a day (Widayati, 2012). Most of the over-the-counter drugs taken via oral administration are consumed with a frequency of three times a day. According to the results obtained from the questionnaires, the participants mostly consumed the analgesic-antipyretic group in their self-medication practice. Analgesicsantipyretics without a doctor's prescription are the most widely circulated in the market with different trade names. This analgesic-antipyretic is basically paracetamol which is also combined with other substances such as decongestants, antihistamines, antitussives or expectorants which are indicated to treat colds and coughs accompanied by fever. Fever is the first symptom of most diseases or disorders, and this is also the main complaint expressed by people when they are sick, so that drugs that treat fever and body aches are used mostly during their self-medication (Supardi \& Notosiswoyo, 2012).

The pretest scores of the participants' answers to the questions in the knowledge and attitudes sections were different from those obtained in the posttest. These differences reflect improvements due to the CBIA learning program. More than $70 \%$ of the participants showed an increase in their knowledge and better attitudes towards self-medication after the CBIA learning method was carried out (Table 3). The scores of the answers to the questions in the knowledge and attitudes sections were then processed using the Wilcoxon test to determine the significance of the differences after the CBIA was implemented. Table 4 shows a significant difference in the participants' knowledge and attitude scores before and after the PKM (CBIA program) was carried out. According to Notoadmodjo (2010), health education to the public can increase their knowledge of the issues or matters that anyone or any institution wishes to inform publicly. However, such an education will not directly promote or encourage behavioral changes as this requires the people's willingness to change their behavior (Lathifah, Susanti, Ilham, \& Wibowo, 2017).

\section{CONCLUSIONS}

Based on the results of the evaluation of the PKM (community service) activity using the two questionnaires, it can be argued this program through the CBIA learning method targeting Sungai Ambawang Community Health Center cadres succeeded in increasing their knowledge and promoting better attitudes regarding self-medication. Efforts to increase 
this knowledge must continue to be carried out, so that people will have a better understanding of the rational use of drugs, especially in the practice of selfmedication.

The CBIA learning method is very important to be taught to communities according to their level of knowledge. Through this method, they will gain knowledge of and skills in filtering correct, clear, and reliable information for the type and amount or number of drugs they are going to use, so that their decisions will be rational.

\section{REFERENCES}

Badan Pusat Statistik. (2007). Survei sosial ekonomi nasional (Susenas). Jakarta

Bennadi, D. (2014). Self-medication: a current challenge. Journal of Basic and Clinical Pharmacy, 5(1), 19-23. DOI: https://doi.org/10.4103/0976-0105.128253

Dinas Kesehatan Kalimantan Barat. (2016). Profil kesehatan provinsi Kalimantan Barat tahun 2015. Retrieved from https://dinkes.kalbarprov.go.id/wpcontent/uploads/2018/08/PROFILKESEHATAN-KALIMANTAN-BARATTAHUN-2015.pdf

Direktorat Bina Farmasi Komunitas dan Klinik. (2006). Pedoman penggunaan obat bebas dan bebas terbatas. Ditjen Bina Kefarmasian dan Alat Kesehatan Departemen Kesehatan Republik Indonesia.

Direktorat Bina Penggunaan Obat Rasional. (2008). Modul II: Materi pelatihan peningkatan pengetahuan dan keterampilan memilih obat bagi kader. Ditjen Bina Kefarmasian dan Alat Kesehatan Departemen Kesehatan Republik Indonesia.

Khairiyati, L. (2015). Faktor yang berhubungan dengan penyimpanan obat keras dan obat antibiotika tanpa resep di Provinsi Gorontalo (analisis data riskesdas 2013). Jurnal Publikasi Kesehatan Masyarakat Indonesia, 2(1).

Lathifah, M. A., Susanti, S., Ilham, M., \& Wibowo, A. (2017). Perbandingan metode cbia dan fgd dalam peningkatan pengetahuan dan ketepatan caregiver dalam upaya swamedikasi demam pada anak. Pharmaceutical Sciences and Research, 2(2), 89-100.

Pemerintah Kabupaten Kubu Raya. (2018). Rekapitulasi puskesmas kabupaten Kubu Raya. Retrieved from http://www.bankdata.depkes.go.id/puskesmas/la poran_puskesmas_detail_kab.php?kd_propinsi= 61\&kd_kabupaten=12\&tahun=2017\&nama_kab upaten=KAB.\%20KUBU\%20RAYA

Soekidjo, N. (2010). Ilmu perilaku kesehatan. Rineka Cipta: Jakarta.

Supardi, S., \& Notosiswoyo, M. (2012). Pengobatan sendiri sakit kepala, demam, batuk dan pilek pada masyarakat di Desa Ciwalen, Kecamatan Warungkondang, Kabupaten Cianjur, Jawa
Barat. Pharmaceutical Sciences and Research (PSR), 2(3),

134-144. DOI: $10.7454 /$ psr.v2i3.3390

Supardi, S., \& Susyanty, A. L. (2010). Penggunaan obat tradisional dalam upaya pengobatan sendiri di Indonesia (analisis data susenas tahun 2007). Buletin Penelitian Kesehatan, 38, 80-89. Retrieved from http://ejournal.litbang.kemkes.go.id/index.php/ BPK/article/view/100/174

Suryawati S. (2003): CBIA: Improving the quality of self-medication through mothers' active learning. essential drugs monitor. World Health Organization. Geneva, 32, 22-2

Untari, E. K., Supardi, S., \& Sauriasari, R. (2017). Comparison between the effect of the community-based interactive approach and the influence of the distribution of booklets regarding the self-medication knowledge, attitude, and behavior of students. Asian Journal of Pharmaceutical and Clinical Research, 10 (Special Issue October), 90-92. DOI:10.22159/ajpcr.2017.v10s5.23106

Widayati, A. (2012). Swamedikasi di kalangan masyarakat perkotaan di kota Yogyakarta. Jurnal Farmasi Klinik Indonesia, 2(4), 145-152. Retrived from https://jurnal.unpad.ac.id/ijcp/article/view/1277 $4 / \mathrm{pdf}$ 